Journal of Contemporary China (2012), 21(78), November

\title{
Explaining Change and Stability in Cross-Strait Relations: A Punctuated Equilibrium Model
}

\author{
WEIXING HU ${ }^{1}$
}

Relations across the Taiwan Strait have experienced several cycles over the last 60 years. Tension and crisis seem to come and go, followed by periods of peace and stability. What explains the cyclical pattern of change and stability? How can we explain the sources of change and stability in the relationship? This article examines the last 60 years' cross-Strait relations in light of an interpretative framework of "punctuated equilibrium." Cross-Strait relations are complex, consisted of actors at the domestic, cross-Strait, and international levels. With a high degree of economic interaction, the cross-Strait relationship can be characterized as economic integration cum political impasse. This article analyzes the cyclical changes through three causal factors: a) the role of issue cycles in cross-Strait relations; b) the impulsive drivers for change, and c) the structural constraints dampening change.

Relations across the Taiwan Strait have shown a cyclical pattern of change and stability over the last 60 years. Many view this pattern as an oscillation between peace and conflict or times of détente alternating with times of tension and crisis. The first 30 years (1949-1979), starting from the Kuomintang's (the Nationalist Party) defeat and retreat to Taiwan, saw a pattern of power competition and armed conflicts, based on ideological rivalry and political hostility. When China under Deng Xiaoping started economic reforms and a new peaceful unification policy toward Taiwan in 1979, the two sides of the Strait toned down hostile rhetoric and resumed economic and social contacts. Yet, peaceful engagement and economic relations cannot solve the fundamental impasses inherent in the relationship. During the Lee Teng-hui period (1988-1999) and Chen Shui-bian period (2000-2008), peace and stability in cross-Strait relations were punctuated by periodic tension and crisis.

With a high degree of economic interaction, the cross-Strait relationship can be characterized as economic integration cum political impasse. Over the past 60 years, tension and crisis seem to come and go, followed by periods of peace and stability. Why have cross-Strait relations cycled like this over the past 60 years? How can we explain the sources of change and stability in the relationship? One explanation is

\footnotetext{
${ }^{1}$ Weixing $\mathrm{Hu}$ is an Associate Professor of Political Science in the Department of Politics and Public Administration, University of Hong Kong. He can be reached by email at rwxhu@hku.hk.
} 
that the domestic foundation for stable cross-Strait relations began to erode as Taiwan's political system was democratized since the early 1990s. When a more democratized Taiwan embarked on its search for a new national identity, competing nationalisms on the two sides are bound to come on a collision course. ${ }^{2}$ While the "identity politics" drive the two sides further apart, commerce and economic ties seem to bring them closer. $^{3}$ As some analysts argue, any equilibrium in cross-Strait relations is inherently unstable, and tension or conflict will drive relations back to a status quo of deadlock from which a new cycle can again start. This is because the state of neither war nor peace is determined by the logic of "a continuing status quo of deadlock." ${ }^{4}$

This article supplements the above discussion with a new analytical perspective. It examines the last 60 years' cross-Strait relations in light of an interpretative framework of "punctuated equilibrium." The punctuated equilibrium model, first developed by paleontologists Niles Eldredge and Stephen Jay Gould, argues that major change do not happen over a gradual course but in localized and sudden events of branching speciation, as opposed to a gradual evolution of Charles Darwin. In this article I analyze the dynamics of the oscillation between peace and tension and how periods of relative stability have transferred to periods of change and tension in crossStrait relations. The punctuated equilibrium model provides the basis for delineating the conditions for cycles of change and stability. There is clearly a high degree of stability built in the cross-Strait relations as seen in the strong maintenance force of the status quo across the Taiwan Strait. The stabilizing force can be attributed to such factors as domestic constraints in Taiwan, economic development and peaceful unification strategy of Beijing, and Washington's concerns about peace and stability in East Asia and its leverage over Taipei and Beijing. Yet, in the last two decades, cross-Strait relations have undergone some major changes resulting mainly from emerging actors in Taiwanese politics and actions and reactions in the cross-Strait interplay between Beijing and Taipei. So without a dynamic theory of change, we cannot fully understand the cyclical pattern of cross-Strait relations.

Cross-Strait relations are complex, consisted of actors at the domestic, cross-Strait, and international levels. The three main actors in the big triangular relationship-Beijing, Taipei, and Washington--pursue different policy objectives and assess change and its implications from its own interest. Closely connected with the big triangle, the interaction between the KMT, Democratic Progressive Party (DPP) and the Chinese Communist Party (CCP) constitutes a small triangle in cross-Strait

\footnotetext{
${ }^{2}$ See, for example, Steve Yui-Sang Tsang and Hung-mao Tien, eds., Democratization in Taiwan: Implications for China (London: MacMillan Press, 1999); Chao Chien-min, "Will Economic Integration between Mainland China and Taiwan Lead to a Congenial Political Culture?" Asian Survey, vol.43, no.2, pp.280-304; and Daniel Lynch, Rising China and Asian Democratization, Stanford, CA: Stanford University Press, 2006.

${ }^{3}$ Leng Tse-Kang, "State and Business in the Era of Globalization: the Case of Cross-Strait Linkages in the Computer Industry," The China Journal, issue 53 (2005), pp.63-79, and Scott L. Kastner, Political Conflict and Economic Interdependence Across the Taiwan Strait and Beyond, Stanford, CA: Stanford University Press, 2009.

${ }^{4}$ Steven M. Goldstein, "The Taiwan Strait: A Continuing Status Quo of Deadlock?" Cambridge Review of International Affairs, vol.15, no.1 (2002), pp.85-94. Also see Jacques de Lisle, "Vicious Cycles and Virtuous Cycles: International Contexts, Taiwan Democracy, and Cross-Strait Relations," in Cross-Strait at the Turning Point: Institution, Identity and Democracy, ed., I Yuan, Taipei, Taiwan: Institute of International Relations, National Chengchi University, 2008.
} 
relations, and this small triangle increasingly becomes the most active driver for future change and stability. Considering this two-tiered structure of cross-Strait relations, this article proposes to explain the cyclical changes over the last 60 years by looking at three causal factors: a) the role of issue cycles in cross-Strait relations; b) the impulsive drivers for change, and c) the structural constraints dampening change. Following the introduction, the second section briefly discusses how the punctuated equilibrium model can contribute to our understanding of the cycles of change and stability in cross-Strait relations. The third section describes three cycles of change and stability over the past 60 years. Then it is followed by a section on the issue cycles and impulsive drivers for change. The fifth section analyzes the structural constraints that bring changes back to equilibrium or a dynamic status quo.

\section{Cycles of Change and Stability and Punctuated Equilibrium}

In a generic sense, cycles of change and stability occur when new issues arise and reconfiguration of power and redistribution of interest occur. Interpreting cycles of change and stability in cross-Strait relations requires us to understand actors, issues, and conditions for change. Actors are the most important factor in moving the cycle of change and stability. In a simple system of what Herbert Simon described as "satisficing", most actors are "satisficers" who seek satisfactory solutions rather than optimal ones or accept choices that are "good enough" for their purposes. ${ }^{5}$ Yet some actors in the system are motivated to seek change as they become dissatisfied with the "status quo". The challengers of the status quo have strong incentives to undercut existing systemic forces and undermine stability by creating new policy issues for public debate. Their strong dissatisfaction not only leads them to demand for policy change but also structural changes. Yet the cross-Strait relationship, like other enduring rivalries for power and sovereignty, has deep-seated raison d'être for continuity due to the cultural and ethnical ties and the civil wars history. Its cycle of change and stability is a different play from those in domestic politics, as it involves forces and constraints at the cross-Strait relations as well as the international level.

The cycles of change and stability in cross-Strait relations, however, have not occurred in an incremental fashion, rather in a punctuated equilibrium fashion. "Punctuated equilibrium" is a theory in evolutionary biology first introduced by paleontologists Niles Eldredge and Stephen Jay Gould. In their seminal paper published in 1972, the two paleontologists challenged the Darwinist evolution theory. They argue that the degree of phyletic gradualism attributed to Darwin is virtually nonexistent in fossil record. ${ }^{6}$ While the theory of gradualism argues that evolution occurs uniformly by smooth and continuous transformation of whole lineages, the punctuated equilibrium theory disputes that major evolutionary changes don't happen over a gradual period but in localized, rare, rapid events of branching speciation. Later on, the model of punctuated equilibrium was applied to the study of social sciences to reconstruct patterns of change and stability in social and policy developments. It is useful to show how social and policy changes are punctuationally

\footnotetext{
${ }^{5}$ Herbert Simon, Models of Bounded Rationality, vol.3, Cambridge, MA: The MIT Press, 1997, pp.291-95.

${ }^{6}$ Eldredge, Niles and S. J. Gould (1972). "Punctuated equilibria: an alternative to phyletic gradualism" In T.J.M. Schopf, ed., Models in Paleobiology. San Francisco: Freeman Cooper. pp. 82115. Reprinted in N. Eldredge Time frames. Princeton: Princeton University Press, 1985, pp. 193-223.
} 
disrupted and then reformulated, rather than gradually altering over time. As Stephen Jay Gould observes, "plateaus of stagnation and bursts of achievement might express a standard pattern for human learning”, and human learning generally proceeds through plateaus of breakthroughs, and that "important changes in our lives occur more often by rapid transition than by gradual accretion."7

Inspired by the biological theory of punctuated equilibrium, social scientists try to find ways to explain complex social change and, particularly, patterns of social change over time. For social scientists, while incremental change remains the most normal pattern of social development, large social shifts do happen and these massive shocks should deserve more attention. Stephen Krasner uses the punctuated equilibrium concept to describe the pattern of change in political institutions. He argues that political institutions are sticky and perpetuate themselves for a time, but as tension builds up crises are required to diffuse the increasing tension and punctuated changes occur. ${ }^{8}$ In the study of international relations, the punctuated equilibrium model has been applied to the study of changes in international energy regime complex, ${ }^{9}$ international environmental regimes, ${ }^{10}$ and changes in international norms. ${ }^{11}$ Paul Diehl and Charlotte $\mathrm{Ku}$ use the punctuated equilibrium model to explain why there are infrequent but influential changes in the international legal system. To them, the interaction between operating and normative systems in international law leads changes in one system that precipitates changes and create capacity in the other system. ${ }^{12}$

The study of public policy and institutional evolution used to be dominated by traditional theories arguing that changes take place incrementally due to the vested interests, bounded rationality, and institutional cultures. By introducing the punctuated equilibrium model to the study of policy change, Frank Baumgartner and Bryan Jones were among the first to describe a life cycle of public policy. They argue that policy change occurs in extended periods of stasis, punctuated by sudden shifts in radical change. The life of a policy process is characterized by long periods of stasis, punctuated by large but less frequent shifts in government and social environment. So in that sense, the punctuated equilibrium model sketches a disjoint and abrupt process of policy change, with long periods of stability separating the shifts. ${ }^{13}$ Policy change is a complex process, and sometimes takes a nonlinear life cycle. Once a policy is formulated or adopted, it takes a long period of consolidation during which relatively small changes occur over time and the existing institutions have inertia to continue the course until major change occurs. To Baumgartner and

\footnotetext{
${ }^{7}$ Stephen Jay Gould, The Structure of Evolutionary Theory, Cambridge, MA and London, England: The Belknap Press of Harvard University Press, 2002, P.957.

${ }^{8}$ Stephen D. Krasner, "Approaches to the state: Alternative conceptions and historical dynamics," Comparative Politics, vol.16, no.2 (January 1984), pp.223-246.

${ }^{9}$ Jeff D. Colgan, Robert O. Keohane and Thijs Van de Graal, "Punctuated Equilibrium in the Energy Regime Complex," Review of International Organizations, published online 26 July 2011.

${ }^{10}$ Oran R. Young, International Dynamics: Emergent Patterns of International Environmental Governance, Cambridge, MA: MIT Press, 2010.

${ }^{11}$ Gary Goertz, International Norms and Decision Making: A Punctuated Equilibrium Model, Lanham, MD: Rowman \& Littlefield, 2003.

${ }^{12}$ Paul F. Diehl and Charlotte Ku, The Dynamics of International Law, Cambridge and New York: Cambridge University Press, 2010.

${ }^{13}$ Frank R. Baumgartner and Bryan D. Jones, Agendas and Instability in American Politics, Chicago, IL: University of Chicago Press, 1993.
} 
Jones, the policy life cycle encompasses both incremental adjustment and nonincremental change within the policy subsystems when the policy could no longer contain the demands for change. ${ }^{14}$

Similar to the biological version of the theory, the punctuated equilibrium theory in social sciences examines large changes in a relatively long-term perspective, spanning from decades to hundreds of years. The empirical validity of the punctuated changes requires a large set of data that track policy stasis and change over the whole life cycle of a policy. For example, True, Jones, and Baumgartner try to explain radical policy changes by examining the rise and fall of the American federal budgets over periods of more than a hundred years. ${ }^{15}$ By the same token, Aaron Wildavsky chose to study the U.S. federal budgets over fifteen years. ${ }^{16}$ But for Wildavsky, the purpose of his study was not to validate the punctuated equilibrium model, rather, to develop a cultural theory of budgeting that explains the degree of balance between revenue and expenditure and why government grows in all industrial democracies from a framework of incremental change.

While the incremental framework emphasizes on constant small changes, the punctuated equilibrium model highlights major shifts in policy process. If the former describes the normal pattern of policy development, the latter portrays large shifts in a punctuated pattern together with periods of policy stability. The difference between the two models can be illustrated below by a straight linear line and a nonlinear line with stasis as well as wide margin of up and down.

Figure 1. Two Patterns of Change \& Stability over Time

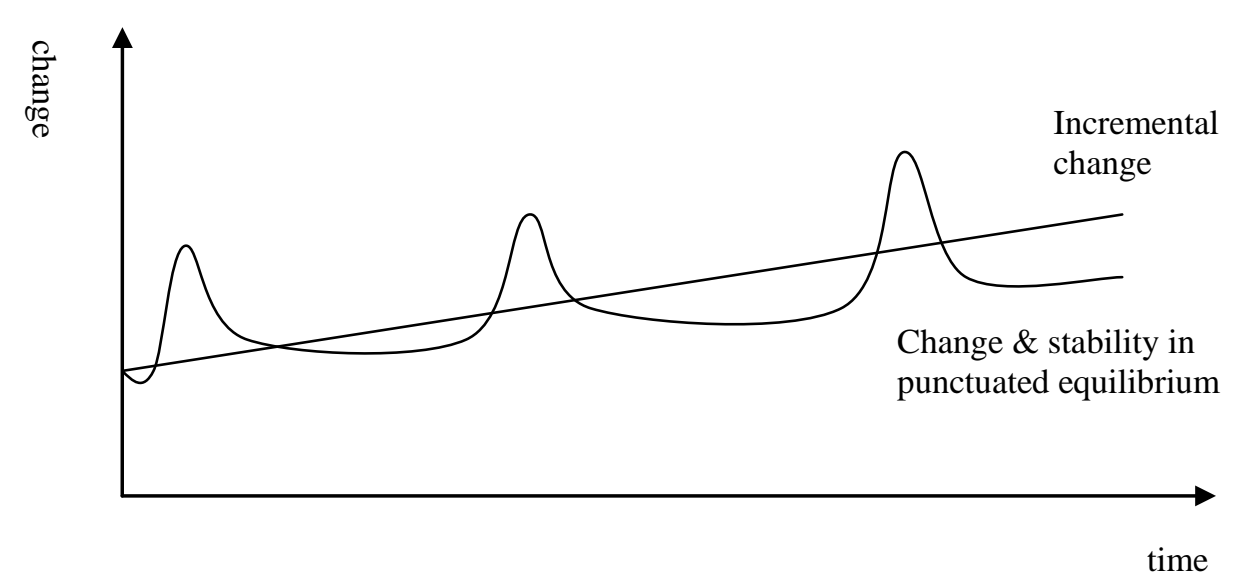

\footnotetext{
${ }^{14}$ Frank R. Baumgartner and Bryan D. Jones, eds., Policy Dynamics, Chicago, IL: University of Chicago Press, 2002, pp.29-46.

${ }^{15}$ James L. True, Bryan D. Jones, and Frank R. Baumgartner and Jones, "Punctuated-Equilibrium Theory: Explaining Stability and Change in Public Policymaking," in Theories of the Policy Process (2nd ed.), ed. Paul A. Sabatier, Boulder: Westview Press, 2007, pp.97-116.

${ }^{16}$ Aaron Wildavsky, Budgeting: A Comparative Theory of Budgeting Process, Boston, MA: Little, Brown, 1975.
} 
The punctuated equilibrium model describes alternative periods of stability and changes in policy and relationship. To what extent can this model explain the change and stability in cross-Strait relations over the last 60 years? There are at least three relevant insights. First, concerning why and how policy change occurs in cycles, we can see each cycle signifies the emergence and recession of policy issues in the public agenda. When a new issue appears or is introduced, public attention on the issue arises. As the policy issue changes, public attention shifts. This is exactly the "invisible hand" behind the cycles in cross-Strait relations.

Second, policy issues are created by politicians and policymakers, so the role of political actors in agenda setting matters. There is conflict of forces that reinforce or question the existing policy. Existing policy is exacerbated by institution and balance of political power. Political elites play a critical role in shaping and changing the public debate and hence setting the agenda for policy change. Agenda setting shifts public attention and explains the prioritization of policy issues in public debate. By focusing on attention shift and agenda setting, we can find that in the case of policy change, actors across the entire political system shift attention collectively and "entering new policy domains is more punctuated than withdrawing from old ones." ${ }^{17}$

Third, what causes the change is another interesting aspect the model directs our attention at. Baumgartner and Jones have introduced "positive feedback" and "negative feedback" to analyze the equilibrium in politics. ${ }^{18}$ The forces for change include social learning, crisis, institutional changes, and the role played by political entrepreneurship. They could be both structural/institutional or behavioral forces. The agenda-setting perspective has recognized the critical role of information and policy entrepreneurs in the policy process. Yet problem definition does not generally occur in a vacuum. All social problems are embedded in given social environment and structure. We should look for source of change from both behavioral and structural perspectives. This is because impulsive forces for change are eventually constrained by structural attributes.

Therefore, the punctuated equilibrium model, as it is applied to studying policy change, cannot fully account for policy dynamics and the mechanisms of the changestability cycle and what really tips the equilibrium for change in particular. For a long time, election is considered as the standard model for policy change in democratic systems since election indicates the public's preferences and creates the mandate for policy change. In today's Taiwan political environment of intensive partisanship and polarization, one might be tempted to conclude that only election matters and incremental changes are not relevant. But the "election matters" model treats the sources of change as fully exogenous, and many policy changes occur in the absence of electoral change — such as leaders' new policy declarations, domestic and external crisis, and rising public awareness of certain issues. If we use the path dependence theory to look at cross-Strait relations, we can find the weight of precedents, institutional separation of power, partisan politics, and interest groups, etc.

\footnotetext{
${ }^{17}$ Bryan D. Jones and Frank R. Baumgartner, The Politics of Attention: How Government Prioritizes Problems, Chicago, IL: University of Chicago Press, 2005, p.199.

${ }^{18}$ Baumgartner and Jones, op. cit (1993), pp.16-18.
} 
has a strong reinforcement effect on the status quo. Yet massive policy shifts do occur in Taiwan without election. Leaders do use policy adjustments and public awareness to accumulate energy for change. The build-up of what Gould calls "plateaus of stagnation” will eventually break the equilibrium at play.

There are of course both indigenous and exogenous disturbance that trigger changes. The U.S. and the mainland China are shadow players in Taiwanese politics. Theories of change and dynamics also tell us there are both long-run determinants that make cross-Strait relations ripe for change (such as economic interdependence and social linkages) and short-term elements such as electoral victory and leadership change. The shifting fundamental economic trend across the Taiwan Strait is an important factor that makes the cross-Strait relationship ripe for change.

\section{Cycles of Stability and Change in Cross-Strait Relations, 1949-2012}

Before discussing the cycles of change and stability, we need to understand the structural complexity of cross-Strait relations. The relationship is complex and dynamic. By nature, the dynamics of the relationship must be conceived and studied as three "two-level games" ${ }^{19}$ within the China-U.S.-Taiwan triangular relationship. Within the big triangle, there are two important bilateral two-level games that mutually affect one another: (1) the cross-Strait interplay that is deeply rooted in domestic politics in Taiwan and in the mainland China; and (2) China-U.S. relations , a relationship between two major powers that have significant impacts on regional and global affairs as well as cross-Strait relations. Concerning the cross-Strait relationship, there are different advocacy coalitions in Taiwan politics, consisting of actors from political parties and social organizations that actively campaign for particular policy issues. ${ }^{20}$ Nationalistic leaders on the both sides of the Strait have to gain domestic support to sustain their power position. Cross-Strait political and economic relations are of paramount importance for all parties concerned. While Beijing and Taipei compete for influence at the cross-Strait level, two big parties in Taiwan, the KMT and DPP, are pitted against each other at the domestic level. Their relations with the CCP could also used as a leverage in political competition. For Beijing, although both economic development and political reunification are important missions, the latter is rather a long shot. At the international level, the cross-Strait relationship is overshadowed by the competitive and cooperative relations between the United States and China. For the United States, its policy toward crossStrait relations is based on strategic considerations of its national interest in East Asia.

\footnotetext{
${ }^{19}$ The concept of "two-level game" was first developed by Robert Putnam. See his article entitled "Diplomacy and Domestic Politics: The Logic of Two-Level Games," International Organization. vol.42 (Summer 1988), pp.427-460.

${ }^{20}$ Paul A. Sabatier and Hank C. Jenkins-Smith, "The Advocacy Coalition Framework: An Assessment”, in Theories of the Policy Process, eds. Paul A. Sabatier (Boulder, CO: Westview Press, 1999), pp.117-166.
} 
Figure 2 China-U.S.-Taiwan Triangle

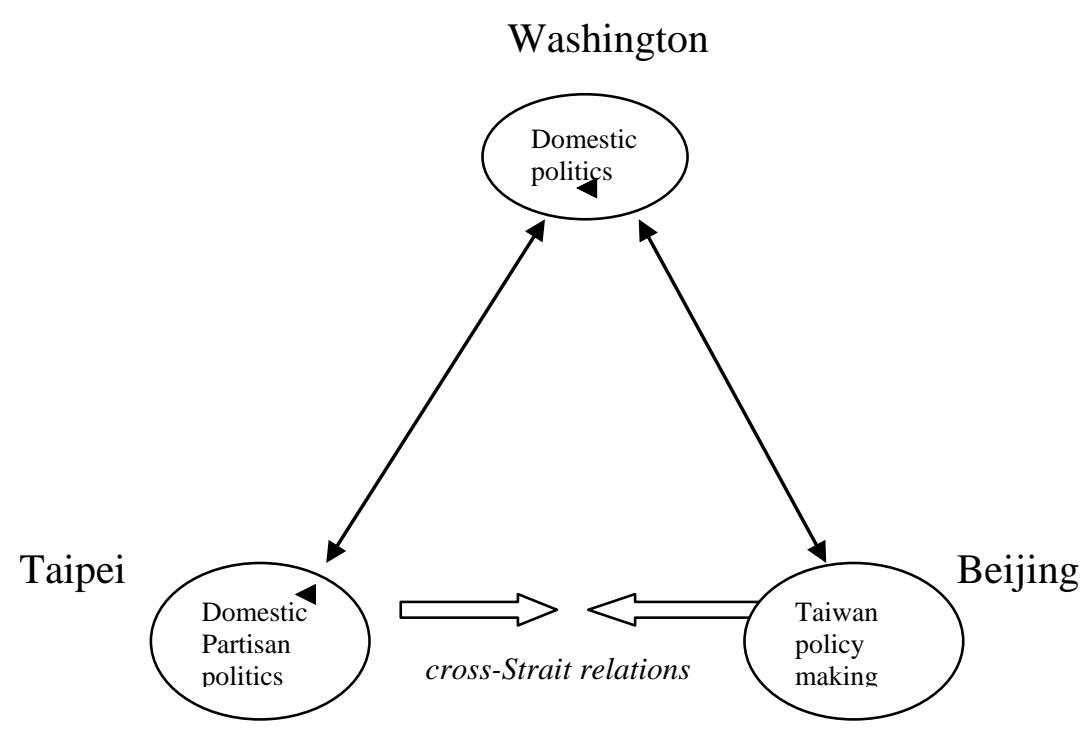

Within this big triangular framework, there are six variables: three domestic political processes (at the three corners) and three bilateral relationships (represented by the three sides of the triangle). For the last 60 years, Taiwan, as the smallest player in the triangle, has been an "underdog" in the triangular game. ${ }^{21}$ However, Taipei's role in the triangle has changed dramatically since the early 1990s. It has taken a series initiatives at home and toward the mainland, and actually turned itself into what Su Qi calls "a tail that could wag two dogs" over the last two decades.

There are different ways of delimiting periods in the last 60 years' cross-Strait relations. ${ }^{22}$ For this study, three cycles of change and stability are identified according to the pattern of rise and fall of tension and contentious issue involved. These three cycles are: (a) 1949-1979; (b) 1979-1999; and (c) 1999-present. Each cycle includes the rise and fall of tension over some contentious issue, followed by a period of détente. To interpret the curvilinear trend, it is important to identify the dominant contentious issue(s) within each cycle that drove up tension and the conditions under which a policy issue cycle was exhausting. A policy life cycle is defined as stages of issue recognition, policy debate, agenda setting, policymaking, implementation, and feedbacks. ${ }^{23}$

\footnotetext{
${ }^{21}$ The idea of this diagram is adopted from Su Chi's concept of "a tail wags two dogs.” See Su Chi, Taiwan's Relations with Mainland China: a Tail Wagging Two Dogs, London and New York: Routledge, 2009.

${ }^{22}$ See, for example, Shao Zhong-hai, Research into Cross-Strait Relations(兩岸關系)，Taipei, Taiwan: Wu Nan Publisher, 2006, and Allen Wachman, Why Taiwan? Geostrategic Relations for China's Territorial Integrity, Stanford, CA: Stanford University Press, 2007.

${ }^{23}$ Paul Cairney, Understanding Public Policy: Theories and Issues, Hampshire, UK: Palgrave Macmillan, 2012, pp.32-34, and Christopher J. Bosso, Pesticides and Politics: The Life Cycle of a Public Issue, Pittsburgh, PA: University of Pittsburgh Press, 1987.
} 
(1) The first cycle (1949 to 1979): rivalry over power and sovereignty. The relationship across the Taiwan Strait in this period was in a state of military and diplomatic war first and then turned to détente. The contentious issue was which side of the Strait had sovereign power to rule China and who represented China in the world. Both sides tried to change the status quo by overpowering the other in competition. The high points of tension were two Taiwan Strait Crises.

Following the founding of the PRC in Beijing on October 1, 1949, the Kuomintang government was forced to retreat to Taiwan and the KMT-CCP power struggle and civil war turned to an cross-Taiwan Strait confrontation. From 1949 to the early 1960s, the cross-Strait relationship was not just in a period of Cold War but also in hot war and armed conflict across the Taiwan Strait. After his defeat in the mainland, Chiang Kai-shek still attempted to reclaim his rule of the mainland, and ordered a series of blockade operations of ports in the mainland, air bombing of key coastal cities, and a series of cross-border raids into south and western areas in the mainland. For Beijing, Mao Zedong wanted to continue to liberate the whole China, including the island of Taiwan. The first Taiwan Strait Crisis began when the two sides first fought over offshore islands in Kinmen in 1949, Dachen Islands in 1954, and the nearby Yijiangshan Island in 1955. These offshore islands were considered as the first line of defense against the communist invasion and footholds to attack the mainland. The armed conflicts over these islands were what is called the first Taiwan Strait Crisis and ended when Beijing ceased bombardment of Kinmen and Matsue islands in 1955.

The second Taiwan Strait Crisis started when the mainland resumed artillery bombardment of Kinmen and Matsu islands on August 23, 1958. There were also air and naval engagements between the two sides in blocking and counterblocking the supply line to the islands. ${ }^{24}$ After the first crisis, the United States entered a common defense treaty with Taipei to prevent military invasion from the mainland. By the treaty commitment, Washington ordered the U.S. navy escort of a convoy of the Taiwanese supply ships to the islands. For Beijing, the PLA was ordered to refrain from shelling on the U.S. escort ships. The Kinmen shelling later became a political game than real war when Beijing announced an "even-day cease fire" in October 1958, which means that the mainland would only shell on odd-numbered days and let resupply to Kinmen and Matsu on even-numbered days. In later years live shells were replaced with propaganda shells, and the bombardment was finally terminated in 1979.

On the diplomatic front, the two sides were scrambling for international recognition and support. The two sides were on a tug of war for who was the legal government of China. Since the both claimed to be the legitimate government of China, the definition of "one China" was not in question. The United States and most of Western countries recognized the Nationalist government in Taiwan while the PRC was recognized by the socialist block and nonaligned movement countries. During this period, Washington pursued a dual policy toward Taiwan. On one hand, it provided security protection against the military invasion from the mainland. On the

\footnotetext{
${ }^{24}$ For more detail of the first and second Taiwan Strait Crisis, see, for example, Chen Jian, Mao's China the Cold War, University of North Carolina Press, 2000; John Lewis Gaddis, We Now Know: Rethinking Cold War History, Oxford and New York: Oxford University Press, 1997, pp.249-252; Lambert M. Surhonem Miriam T. Timpledon, and Susan F. Marseken, Second Taiwan Strait Crisis, Bestascript Publishing 2010, and Peter Jaw, Taiwan vs China 1958, AuthorHouse, 2009.
} 
other hand, it also restrained Taipei from military adventures to retake the mainland because it might drag the U.S. into a war it didn't want. It was not until 1971 that the UN General Assembly passed Resolution No.2758 on October 25, 197 that recognizes the PRC as "the only legitimate representative of China to the United Nations" and expelled the representatives of Chiang Kai-shek from the place which they unlawfully occupy at the UN. Beijing's return to the UN was a big victory for the PRC, and it was followed by President Nixon's decision of the diplomatic opening to China and his historic visit to China in February 1972. In the Shanghai Communiqué issued after Nixon's visit, China and the U.S. agreed to set aside the "crucial question obstructing the normalization of relations" concerning the political status of Taiwan and to open up trade and other contacts between the two countries. Six years later, Washington decided to switch its formal diplomatic relationship from Taipei to Beijing on January 1, 1979. On the same day, the Chinese National People's Congress issued a "Message to Compatriots on Taiwan", in which Beijing announced to stop the bombardment of Jinmen and Matsu and to pursue peaceful ways to solve the Taiwan question. ${ }^{25}$

(2) The second cycle (1979-1999): from détente to tension. This period started with a period of détente and dialogue, but two impetuous events turned the relationship into growing tension and then the Third Taiwan Strait Crisis. Two events were Lee Teng-hui's visit to Cornell University in June 1995 and his "state-to-state relations" statement in July 1999. The emerging contentious issue was whether the two sides of the Strait still coexist in the "One China" framework or their relations are what Lee called "special state-to-state relationship".

The two sides of the Taiwan Strait entered a period of détente after Beijing's new peaceful unification policy in 1979. Although Chiang Ching-kuo rejected Beijing's initial peace offer by reiterating Chiang Kai-shek's "three nos policy," ${ }^{26}$ he allowed Taiwanese to visit their relatives in the mainland in November 1987. After Chiang Ching-guo died in January 1988, the end of Chiang family's rule of Taiwan marked a new era for cross-Strait relations. Lee Teng-hui, a native-born Taiwanese who succeeded Chiang, took initial steps toward cross-Strait reconciliation by allowing more family reunions, personnel exchanges, and even substantive dialogues with the mainland. Beijing reciprocated by welcoming Taiwanese "compatriots" for tourism, investment, and family reunification. The two sides, through government-authorized agencies - the Association for Relations across the Taiwan Strait (ARATS) on the mainland side and the Straits Exchanges Foundation (SEF) on the Taiwan side, reached an oral agreement on the meaning of the "One China principle" in Hong Kong in 1992, and held the first historic direct negotiation in Singapore in 1993.

The phasing out of the Chiang family's influence in Taiwan, however, led to the "Taiwanization" of the island's politics, which planted seeds for future confrontation. To consolidate his power within the Kuomintang (KMT) and the government, Lee Teng-hui embarked on a series of political reforms aimed at transferring political power from the Mainlanders (Waisheng Ren) to the native-born Taiwanese (Bensheng Ren). As a Beisheng Ren, Lee has no interest in "retaking the mainland"

\footnotetext{
${ }^{25}$ The Standing Committee of the Fifth National People's Congress, "Message to Compatriots in Taiwan", full text in http://www.china.org.cn/english/7943.htm.

${ }^{26}$ The "three nos policy" was that "no contact, no compromise, and no negotiation" were allowed with the communist government in the mainland. It was laid down by Chiang Kai-shek after his retreat to Taiwan.
} 
or talking reunification with the mainland. To sever symbolic links with the mainland, Lee initiated and pushed for a series of "localization" measures. He eliminated the Temporary Provisions Effective During the Period of Communist Rebellion in 1991 (which outlawed opposition activities after the KMT retreated to Taiwan in 1949), forced those legislators originally elected to represent mainland constituencies to retire, and dissolved the National Assembly elected in 1946 on the mainland, and later held the first-ever direct presidential election in 1996. Lee's reforms not only helped to consolidate his political power, but also paved the way for the rising power of the DPP, a pro-independence party in Taiwan. ${ }^{27}$

Lee Teng-hui's first head-on confrontation with Beijing came in June 1995 when he paid a high-profile visit to his alma mata Cornell University. Lee's visit triggered a severe cross-Strait crisis as well as strained China-U.S. relations during Bill Clinton's first presidential term since the Clinton Administration granted him a visa to pay this visit. Domestically, Lee's "stand-up to Beijing” drove up his popularity. Across the Strait, Beijing was caught in surprise by the announcement of Lee's visit but had little leverage at disposal to stop that. To contain Lee and intimidate Taiwanese voters in the 1996 presidential election, Beijing carried out large-scale military exercises across the Strait and launched missiles close to Taiwan. These actions had the opposite result of further alienating the Taiwan populace. ${ }^{28}$

Two years later, SEF Chairman Mr. Koo Chen-fu visited the mainland in October 1998 as the tension began to calm down. Mr. Koo met Mr. Jiang Zhemin (Secretary General of the CCP) and his counterpart Mr. Wang Daohan. As the SEF and ARATS were preparing for Wang Daohan's return visit to Taiwan in 1999, Lee Teng-hui surprised everyone again. In July 1999, he abandoned the KMT's traditional “one China” policy and characterized cross-Strait ties as a "state-to-state" relationship. This statement, again, turned the relationship into tension just months before $\mathrm{Mr}$ Wang Daohan's scheduled visit to Taiwan to restore the cross-Strait dialogue. For Beijing, Lee's statement was seen as just a step short of calling for Taiwan independence as the DPP would do. ${ }^{29}$

(3) The third cycle (2000 to 2012): “a tail wagging two dogs”? This cycle spans from two Chen Shui-bian administrations (2000-04, 2004-08) to the 2008 and 2012 elections, both of which returned the KMT to power. The period of twelve years saw the rise and fall of the Taiwan national identity issue and the demise of Chen's drive for Taiwan's de jure independence. In the 2000 presidential election, Chen Shui-bian's victory was the first time in fifty years that a pro-independence party came to power in Taiwan. ${ }^{30}$ During Chen's first term, cross-Strait relations were relatively calm in the first years as Beijing took a wait-and-see policy toward the Chen administration. Yet Chen started to be provocative in August 2002 when he

\footnotetext{
${ }^{27}$ DPP's platform was revised in 1999 that any change of the island's status must be decided through a referendum by all its residents passed. See DPP's “Resolution on Taiwan’s Political Future” (臺灣前 途決議文) on May 8, 1999.

${ }^{28}$ Suisheng Zhao, ed., Across the Taiwan Strait: Mainland China, Taiwan, and the 1995-1996 Crisis. London: Routledge, 1999.

${ }^{29}$ Bruce Dickson and Chien-min Chao, eds., Assessing the Lee Teng-hui Legacy in Taiwan's Politics: Democratic Consolidation and External Relations, Armonk, NY: M.E. Sharpe, 2002.

${ }^{30}$ Shelly Rigger, From Opposition to Power: Taiwan's Democratic Progressive Party, Boulder, CO: Lynne Rienner, 2001.
} 
announced that "one country on each side of the Strait" and "the referendum is urgent." ${ }^{31}$ Later on, he kept pushing the envelope by adopting policies interpreted in Beijing as moving Taiwan closer to formal independence, such as changing names of state entities, referendum, and pushing for a new constitution. Chen's policy challenged the bottom line of both Beijing and Washington's policies toward crossStrait relations. In the 2004 presidential race, he was trailing behind his "pan-blue" rivals in all the polls due in part to an economic slowdown, and he relied on national identity and Taiwan independence as issues to appeal to voters. He even proposed a national referendum on a new Taiwan constitution (Quanmin Gongtou, Cuisheng Xinxian) in an effort to portray his KMT opponents as selling out the Taiwanese people and being easily cowed by Beijing.

Chen's referendum drive mounted a grave challenge to both Beijing and Washington. The Chinese leaders were alarmed. Their perceptions of Taiwan's domestic politics greatly influenced their attitudes regarding the Taiwan issue. ${ }^{32}$ Since the late 1990s, they had tried different strategies to contain Taiwan's proindependence tendency, but none worked. They realized that they had only limited leverage to curb this tendency. The 1996 missile tests proved counterproductive. Stern warnings from Premier Zhu Rongji in 2000 and from Premier Wen Jiabao in 2004 did not work either. Learning from past experiences, the leadership under $\mathrm{Hu}$ Jintao initiated a new strategy which stressed making "the stick harder and the carrot sweeter." A domestic law (the Anti-Secession Law, or ASL, passed by the National People's Congress in March 2005), inspired by the U.S. Taiwan Relations Act (TRA), would draw a clear “red line” to deter Taiwan's formal independence. Concomitantly, commercial benefits to be gained from closer cross-Strait economic integration would offer positive incentives. Meanwhile, Washington also saw the risk of war that could endanger American interests in the Asia Pacific. ${ }^{33}$ Chen's provocation threatened to destabilize U.S. relationship with China. The Bush Administration made it clear that it "oppose(s) any attempt by either side to unilaterally change the status quo in the Taiwan Straits," and "would be opposed to any referenda that would change Taiwan's status or move towards independence." 34 The U.S. government has rarely made such strong comments on Taiwan's affairs. It was a clear indication that Washington had become very displeased with Chen's policy.

The turning point in cross-Strait relations came in the second term of the Chen administration and the two years leading up to the 2008 election. Due to a series of personal scandals, Chen was politically discredited at home and abroad. His rival KMT was running on a platform of rapprochement and downplaying the national identity issue in the 2008 presidential race. The KMT candidate Mr. Ma Ying-jeou proposed a "three nos policy"--no unification, no independence, no use of force. Cross-Strait rapprochement depends on accommodating mutual interests and institutionalizing a modus vivendi in bilateral relations. With increasingly strong cross-Strait economic ties, a high degree of economic integration has become the

\footnotetext{
${ }^{31}$ Chen Shui-bian's telecast speech to the annual conference of the World Federation of Taiwanese Associations in Tokyo, August 3, 2002.

${ }^{32}$ For more discussion on the changing attitudes, see Chien-Kai Chen, "Comparing Jiang Zemin's Impatience with Hu Jintao's Patience regarding the Taiwan Issue, 1989-2012" Journal of Contemporary China, vol.21, no.78 (November 2012), pp.xx-xx.

${ }^{33}$ Michael D. Swaine, “The Trouble in Taiwan,” Foreign Affairs Vol.83, no.2 (2004), pp.39-49.

${ }^{34}$ Remarks by Richard Boucher at the State Department daily press briefing, December 1, 2003.
} 
anchoring force for political détente. Over the last two decades, Beijing has pursued a pragmatic Taiwan policy, suggesting that "political differences should not affect economic cooperation.” Even during the DPP years, it did not shut the economic door but had instead increased attractive terms to Taiwanese businesses.

After he was elected in 2008, Ma Ying-jeou reversed his predecessor's policy and returned to the original KMT policy of cross-Strait relations based on the "one China constitution.” According to Ma, cross-strait relations are not state-to-state relations, but a special kind of relationship between two regions within a country. ${ }^{35}$ As a consequence, both sides now conduct dialogues under a framework of "mutual nondenial”. They view economic integration and social exchanges as part of the general trend of globalization and regional integration in the Asia Pacific. Through the ARATS-SEF dialogues, the two sides of the Strait have signed sixteen agreements since 2008 on issues ranging from direct flights, shipping, food safety, combating crime, tourism, and investment. More and more of their government officials have participated in direct negotiations, thus turning ARATS-SEF dialogues increasingly into government-to-government talks. On June 30, 2010, ECFA (Economic Cooperation Framework Agreement) was signed to map out future cross-Strait economic relations. Likewise, Taiwan's long-standing efforts for a presence in international organizations bore fruit when the World Health Organization (WHO) officially invited Taiwan to participate in the World Health Assembly as an observer in May 2009.

The current round of cross-Strait rapprochement received its jump-start from the historic meeting between the leaders of CCP and KMT in May 2005. CCP General Secretary Hu Jintao and KMT Chairman Lien Chan met in Beijing and issued a "Five Points Common Vision” statement. Because this statement was just a party-to-party agreement, it was not until Ma Ying-jeou's won the 2008 election that it was brought into practice. The rapprochement since then has developed along two lines. First, the two sides have undertaken political dialogue over resolving their political impasse on the basis of the expedient "1992 consensus" (which agreed to the "one China" principle but left the definition of "China” ambiguous). Second, they have embarked on comprehensive exchanges and engagement relations, through increasingly institutionalized cross-Strait dialogue arrangements. To further consolidate détente, Beijing has formulated a long-term strategy of "peaceful development." ${ }^{36} \mathrm{Hu}$ Jintao elaborated this strategy in December 2008 by calling for a comprehensive economic cooperation agreement, more political dialogue to enhance mutual trust and even confidence-building measures (CBM), and finding ways to accommodate Taiwan's aspiration for "international space," in addition to further strengthening economic and cultural ties between the two sides.

Washington has welcomed the new rapprochement across the Taiwan Strait. In the Joint Statement issued after President Hu Jintao's visit to the U.S on January 19, 2011, it applauded the ECFA and the new lines of communications developing between Beijing and Taipei. More importantly, the U.S. "supports the peaceful development of relations across the Taiwan Strait and looks forward to efforts by

\footnotetext{
35 '"Non-state-to-state' discourse based on Constitution: spokesman", Central News Agency, September 11, 2008, http://times.hinet.net/times/article.do?newsid=1727002\&option=english.

${ }^{36}$ The "peaceful development" strategy was initially formulated in the CCP's 17th National Party Congress in October 2007.
} 
both sides to increase dialogues and interactions in economic, political, and other fields, and to develop more positive and stable cross-Strait relations." ${ }^{37}$ Cross-Strait economic integration has reduced the danger of war and the likelihood that U.S.China relations may be seriously damaged over the Taiwan issue.

The waning of the national identity issue can also be seen in the result of the 2012 election in Taiwan. For the first time in Taiwan elections, the national identity and the reunification/independence issue was not on the agenda. Ma Ying-jeou's DPP challenger did not use the national identity issue to mobilize support, nor any tactical moves such as provocative referendum were used. Instead, the national identity issue was largely overtaken by more substantive debates over socio-economic policies, ECFA and leaders' integrity and capability. The "1992 Consensus" was one key issue on the agenda, but the debate was less on its political implication, more on its economic implication.

\section{Explaining Dynamics in Cycles of Change and Stability}

By the above discussion, the dynamics driving the cyclical changes can be seen from the rise and fall of contentious issues and agenda-setting politics on these issues. As Baumgartner and Jones have argued, dynamics for change lies in a continual struggle between the forces of balance and equilibrium (termed as "negative feedback processes") and the forces of destabilization and contagion (termed as "positive feedback processes”). ${ }^{38}$ A disturbance is usually met with countervailing forces in a change process. In contrast to the stabilizing effect of negative feedback processes, positive feedbacks destabilize. The positive feedback process is a self-reinforcing process that accentuates rather than counterbalances a trend. ${ }^{39}$ As such, the punctuated equilibrium model provides a good perspectives, together with other dynamical theories, to detail a specific mechanism (or set of related mechanisms) responsible for policy change.

In Taiwan politics, the KMT represents the "negative feedback" force while the DPP the "positive feedback" force. The disturbance force is usually triggered by raising controversial issues and the agenda setting politics that follows. There are, of course, all kinds of issues--social, cultural, economic, political--in cross-Strait relations. However, one issue stands out from the rest as the most controversial one for cross-Strait relations, and this issue is the controversy on Taiwan's national identity. ${ }^{40}$ Change is path-dependent and incremental. But when major dissatisfied actors want to challenge the status quo, change can be impetuous accompanied by tension and crisis within the system.

Dissatisfied challengers are the impulsive forces within the system that sets off a cycle of change, vicious or virtuous. In the triangular relationship since the 1980s, both Beijing and Washington are more conservative and pro-status quo. Although

\footnotetext{
${ }^{37}$ White House, U.S.-China Joint Statement, January 19, 2011, http://www.whitehouse.gov/the-pressoffice/2011/01/19/us-china-joint-statement

38. Frank R. Baumgartner and Bryan D. Jones, "Positive and Negative Feedback in Politics,” in Policy Dynamics, eds., Frank R. Baumgartner and Bryan D. Jones. Chicago: University of Chicago Press, 1993, pp.3-28.

${ }^{39}$ Ibid, p.13.

${ }^{40}$ Lowell Dittmer, "Taiwan and the Issue of National Identity," Asian Survey, vol.44, no.4 (JulyAugust 2004), pp.475-483.
} 
Beijing sees reunification as its sacred national mission, but CCP leaders, by and large, have remained patient in pushing forward the course. Reunification is a longterm shot, and before it is feasible, Beijing considers a high degree of economic integration with Taiwan is more desirable. Washington's main concern in the Taiwan Strait is peace and stability. As long as cross-Strait relations remain peaceful and stable, Washington does not have strong incentive to change the status quo. Thus political actors within Taiwan have been the most active impulsive forces initiating the cycle of change in the last two decades.

Since the democratization of Taiwan's political system, the KMT has no longer played the dominant role in Taiwanese politics and partisan politics for political power has become more intense. In Taiwanese politics, since most pan-Blue supporters tend to be more pro-unification or pro-cross-Strait rapprochement while pan-Green supporters lean toward Taiwan independence, the national identity issue (to some extent, the so-called ethnical issue) has become a bifurcated issue dividing the society and defining Taiwan's political map. The two political forces, the panblue camp and the pan-green camp, are roughly divided, with the former enjoying a little bit larger voters base over the latter. In Taiwan politics, cross-political camp voting is relatively rare. The implication is that the both parties have to reach out so as to capture more votes, including those voters swinging between the two camps. Appealing to voters' nationalistic sentiment is an effective way to influence public opinions. To get an upper hand in political competition, the DPP has used the most controversial issue --national identity--to appeal to a wider audience over its rival the KMT. Since the national identity issue could sometimes become such a dominant and a highly emotional issue to appeal voters, the DPP under Chen Shui-bian (20002008) tried to play the issue into its own advantage. By playing that issue, the DPP was on offense and kept its rival the KMT on defense in electoral campaign.

The DPP has played the role of a "revisionist" in the triangular game. The party's platform states its ultimate goal is to establish an independent Taiwan which is separated from China. On cross-Strait economic relations, the DPP regards too much economic dependence on the mainland hurts Taiwan and its independence course, so it is opposed to having close economic ties with the mainland China. For the KMT, it stands somewhere between Beijing and the DPP on political issues and closer to Beijing on economic issues. In the two-level game, the KMT is pitted against the DPP for popular support in Taiwan politics. ${ }^{41}$ In setting public agenda, the KMT was in a relatively disadvantageous position vis-a-vis the DPP in the 2000 and 2004 elections, as it is a pro-status quo party and only attracts votes from pro-unification and pro-status quo supporters. The KMT is status quo party because the status quo was in effect defined by the KMT, not the DPP, after the KMT retreated to Taiwan. The political system and institutions were all brought from the mainland to Taiwan by the KMT back in the 1940s, none of which were the DPP's creations. Yet, after rounds of democratization and localization since the late 1980s, the government's effort to define Taiwan as part of China began to lose its credibility.

Taiwan has embarked on a search for a new Taiwanese identity since the Lee Teng-hui years. The Taiwanese public have gone through a process of redefining Taiwan's relationship with the mainland China culturally, economically and

\footnotetext{
${ }^{41}$ Yu-Shan Wu, "Taiwanese Elections and Cross-Strait Relations: Mainland Policy in Flux," Asian Survey, vol. 39, no.4 (July-August 1999), pp. 565-87.
} 
politically. Over the last two decades, there has been an significant transition from a highly contested national identity to a relatively consensual national identity. ${ }^{42}$ As the opinion survey below shows, $54.2 \%$ of respondents say they are "Taiwanese" in June 2011, as opposed only $17.6 \%$ did in 1992. Even though the popular support for the DPP has declined since the revelation of Chen Shui-bian's scandals, the support for a new Taiwanese national identity has actually gone up. ${ }^{43}$ Given the distribution of voters on the national identity issue, it is indeed very difficult for the KMT to have any advantage over the DPP in elections overloaded with heated debates over national identity issues. On the contrary, the national identity issue gave the DPP big advantage in the 2000 and 2004 election, and the party tried to dominate the debate discourse and policy agenda by playing the identity issue. Yet, the DPP under Chen Shui-bian became too "addicted" to playing the national identity issue in elections, and its overplay of the issue saw a "marginal rate of returns" in the 2008 and 2012 elections.

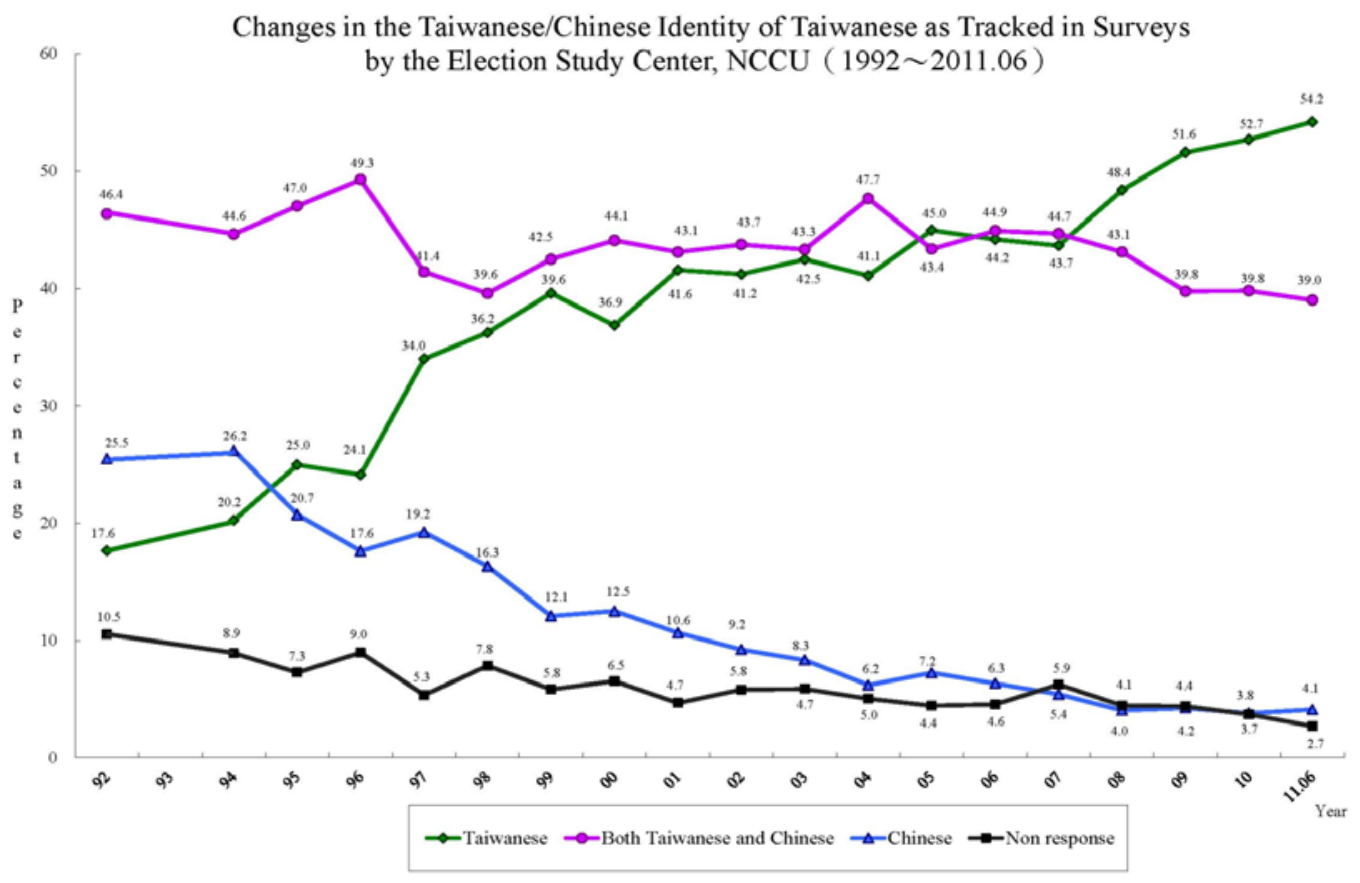

When the national identity issue was used by the DPP as part of its struggle with the KMT, identity politics became a political tool manipulating for electoral advantage. Yet the Chen Shui-bian administration could not manage to address a multitude of problems facing Taiwan in cross-Strait relations when the DPP was in power from 2000 to 2008. Given the globalization trend and fast growing crossStrait economic ties, Taipei has to prioritize competing interests among economic growth, national security, and national identity building. Up until 2000 and after

\footnotetext{
${ }^{42}$ Chien-min Chao, 'National Security vs. Economic Interests: Reassessing Taiwan’s Mainland Policy under Chen Chui-bian,’ Journal of Contemporary China 13 (41) (2004), pp. 687-704.

43 Dongtao Qi, "Divergent Popular Support for the DPP and the Taiwan Independence Movement, 2000-2011," Journal of Contemporary China, vol.21, no.78 (November 2012), pp.xx-xx.
} 
2008, the KMT controlled both executive and legislative branches of government in Taiwan. Beijing started to deal with the KMT bypassing the DPP government. The result of the CCP-KMT direct talks let the Taiwanese public to see an alternative to the cross-Strait stalemate under the DPP rule. This has seriously undermined the DPP's national identity card. The 2008 election saw an overwhelming victory by the KMT. The message from the election was "economy first, politics later." The 2012 election reconfirmed the popular support for the KMT's rapprochement policy with a strong message of "don't rock the boat."

\section{Structural Constraints that Dampen Punctuated Changes}

The cycles of cross-Strait relations show a strikingly similar pattern of a pendulum swinging back and forth. Each time an impulsive change is met by countervailing forces that push it back to the original status quo. How can we explain such countervailing forces or what Baumgartner and Jones call "negative feedback" processes? Are there any structural constraints that dampen punctuated impulses? Steven Goldstein argues that dynamic and cyclical nature of cross-Strait relations is determined by countervailing imperatives built in the status quo. Since all players have ambiguous policies toward each other and their policies contain, within them, seeds for reversal and make any equilibrium inherently unstable. Each equilibrium already contains seeds for change, and tension and crisis lead to a return to status quo. ${ }^{44}$ If stability means the return to status quo and the status quo is a highly dynamic phenomenon, what explains structural mechanisms for the "negative feedback" processes?

Robert Putnam's perspective of two-level games, albeit with additional emphases on the role of major third parties and the effects of "echo chamber," offers a good angle to look at the structural mechanism that dampen punctuated changes in crossStrait relations. ${ }^{45}$ In its essence, the perspective of two-level games argues that the effectiveness of foreign pressure will be limited by incumbent politicians' domestic "win set," and the domestic situation facing these politicians will in turn influence their choice of foreign policies and the effectiveness of these policies. Deals, formal or informal, struck with one's foreign counterparts would have to be "ratified" domestically. Deals could mean implicit or explicit agreements that have the intent of accommodating mutual interests and institutionalizing a modus vivendi to stabilize bilateral relations. Such arrangements with an external counterpart are more vulnerable to reversal when there is sharp domestic dissension and strong foreign opposition. So when politicians are hemmed in by such constraints, they are less motivated and able to launch bold initiatives in the first place, or they have to pay a heavy price for such initiatives when encountering a strong domestic "headwind."

In cross-Strait relations, internal and external conditions for change are the consequences of political leaders' actions in Taipei or Beijing. Whether their policies are successful depends on how they resonate with the political and economic

\footnotetext{
${ }^{44}$ Steven M. Goldstein, "The Taiwan Strait: A Continuing Status Quo of Deadlock?" Cambridge Review of International Affairs, vol.15, no.1 (2002), pp.85-94.

45 Robert D. Putnam, "Diplomacy and Domestic Politics: The Logic of Two-Level Games", International Organization vol.42, no.3 (1988), pp. 427-60.
} 
motivations prevailing in Taiwan and the mainland. The more they are aligned with the existing distribution of influence and interests, the more receptivity they will encounter. Conversely, the more they are misaligned, the more difficulty, even adversity, they will provoke. Beijing's appeal as an economic partner turned out to be more compelling to the Taiwanese populace including DPP constituents even though they might have been more inclined politically to support a pro-independence agenda. But Chen Shui-bian's radical policy of challenging political baseline of Beijing turned out to be more unsettling for the cross-Strait détente process. Even without his personal corruption scandals that eroded his political legacy, the KMT could have easily overturned his cross-Strait policy. That is also why Beijing did not repeat its efforts at military coercion in 1996 and used a soft containment strategy against Taiwan's independence instead.

Powerful economic interests constitute an important constraint on Taiwan's proindependence politicians from "rocking the boat." In the last twenty years we see an interesting example of domestic and international developments "meshing" in promoting cross-Strait détente. This example also illustrates Putnam's point about "the importance of targeting international threats, offers, and side-payments with an eye towards their domestic incidence at home or abroad.” ${ }^{46}$ That is, Beijing's commercial enticements were important not so much because of its average effect on Taiwan's population but rather because of its marginal effect on a pivotal group of power brokers, namely, the internationally-oriented business interests in Taipei.

The rapprochement across the Taiwan Strait was initiated and sustained by economic interests, but this is not to imply that politics did not matter, or that Beijing's agenda for encouraging commerce with Taiwan did not have a strong political motivation. But at least from Taiwan's side, internationally-oriented business firms have become a powerful domestic constituency that advocates and lobbies for increasing cross-Strait commerce. With the passage of time, more people on Taiwan became a stakeholder in expanding economic ties with China, thus making a reversal of policy more difficult given the changing balance of interests and influence in favor of keeping and even increasing these economic ties. This is in stark contrast with the rapprochement on the Korean peninsula, which had stronger political than economic motivation because North Korea promises few immediate economic returns for South Korea. Economic motivations have therefore presented a less compelling force for Korean rapprochement. So the situation of "economic integration cum political impasse" implies that a pro-independence agenda would have to overcome powerful economic interests that have acquired a strong stake in continuing and expanding commerce across the Taiwan Strait.

As the mainland and Taiwan become more interdependent economically, Beijing has gained more confident that this interdependence will improve its advantage over Taiwan in the long run. Growing economic ties reassure Taiwan's continued cooperation and eventual peaceful reunification. ${ }^{47}$ Beijing learned that coercive diplomacy can be counterproductive and play into the hands of the pro-independence forces in Taiwan. It has become more restrained and careful in reacting to the

\footnotetext{
${ }^{46}$ Putnam, ibid, p.460.

${ }^{47}$ Steve Chan, "Commerce between Rivals: Realism, Liberalism, and Credible Communication across the Taiwan Strait," International Relations of the Asia Pacific, vol.9, no.3 (2009), pp.435-467.
} 
"election languages" of political parties in Taiwan. The Chinese leaders realize that the hardball tactics and harsh rhetoric of the past had driven Taiwan further away from the mainland. To remedy this, they have embarked upon a "hearts and minds" strategy aiming to win over Taiwan's populace. They have opened the mainland market to agricultural products from southern Taiwan (a traditionally pro-Green area); mainland universities offer preferential treatment to Taiwanese students; academic scholars from both sides regularly hold joint conferences; Taiwanese businesses receive low-cost loans for investing on the mainland; daily direct cross-Strait flights help revitalize Taiwan's ailing airline industry and airports; and the influx of mainland tourists provide tangible gains to Taiwan's economy. For Taiwan, growing economic ties have helped Ma Ying-jeou's KMT to refocus the political debate on economic issues, not on identity issues. Ma's economic appeal helped him to prevail in the 2008 and 2012 presidential election. As Taiwan's economy faces rising unemployment and sluggish growth after eight years of the DPP rule and the compound effect of the global financial crisis, the economic opportunity presented by China has been highly attractive. Taiwan's businesses have invested heavily in China, and they have become strong stakeholders in cross-Strait stability. As East Asian countries are busy forging free trade agreements with one another, Taiwan is concerned about becoming marginalized in this movement toward regional economic integration.

The structural constraint also comes from Washington. Instead of abetting Chen Shui-bian, Washington had sought to restrain him. Even President George W. Bush, who at the start of his administration stated publicly that he would "do whatever" to assist Taiwan, found himself rebuking Chen's referendum on United Nations membership. After several serious downturns in its relations with Beijing, such as over the issuance of a visa for Lee Teng-hui to visit Cornell University, the U.S. sought to discourage pro-independence forces on Taiwan. Pro-independence politicians found less domestic support in part because their preferred policy appeared to have little chance of success without U.S. support. The reverberations hamstrung officials on both sides and constrained their political elbow room or domestic "win sets." Significantly, Beijing exercised self-restraint even in the face of Chen's repeated provocations, and this restraint was also greatly assisted by Washington's intervention to discourage Chen from taking even more provocative policies due to U.S. concerns about military escalation. This non-occurrence was in turn important because it did not produce a political backlash in Taipei that could have mobilized popular support against rapprochement. This is important because of the dynamics of tit-for-tat such that hardliners could feed off reciprocal bellicosity, in effect turning them into each other's most effective allies in ratcheting up tension and in sustaining this tension.

Washington's policies have had the effect of restraining Chen Shui-bian, making it less necessary for Beijing to pursue hard-line policies. This policy shift created a tacit alignment with Beijing and some scholars even label it as "co-management." signified a turn-about on Washington's part. Before September 11, 2001, the George W. Bush administration adopted a pro-Taiwan stance. After September 11, it sought

\footnotetext{
${ }^{48}$ Zhao Quansheng, "Moving toward a Co-Management Approach: China’s Policy toward North Korea and Taiwan,” Asian Perspective vol.30, no.1 (2006), pp.39-78.
} 
improved relations with Beijing, and its "rebalancing” helped to stabilize cross-Strait relations. For Washington, a stable and healthy cross-Strait relationship is in the interest of both Washington and Beijing, with both of them interested in curbing the DPP's drive toward de jure independence. With Washington's help to contain Taiwan independence, Beijing was able to adopt a more "liberal” approach toward Taipei, which serves Washington's interest in the region as well. Thus, the realignment of interests between Beijing and Washington set the table for future cross-Strait rapprochement on the basis of a common minimum denominator of "no independence; no use of force; and no change in status quo."

By this logic, relations across the Taiwan Strait are embedded in and even derivative of the U.S.-China relations. It is increasingly the case as China arises rapidly to the big power status. While the U.S. and China are exploring for a new type of strategic relatons, Taipei's cross-Strait policy is motivated by a different agenda. Yet when Chen Shui-bian's policy pushed for de jure separation from China or played the national identity issue to his advantage in political competition, it would collide with the two big powers' policy agenda. It ran contrary to the thrust of U.S. policies which have generally tried to engage and accommodate China and maintain peace and stability in the West Pacific region. Thus, the détente process across the Taiwan Strait managed to survive notwithstanding a pro-independence president in Taipei. When Lee Teng-hui and Chen Shuibian tried in their respective ways to be agenda setters in addressing relations with China, they turned in the end to be agenda takers in reacting to situations dictated by Washington's strategic calculus.

Punctuated changes are usually initiated by impulsive forces. Lee Teng-hui and Chen Shui-bian are both revisionist leaders in the triangular game. As political mavericks, they overcame long odds to capture the presidency. Their status as political outsiders and indeed literally political prisoners would naturally explain their disposition to challenge policy orthodoxies and to propose "new thinking." It is therefore unsurprising that they undertook initiatives that tried to break away from the past. Their political base tended to be limited and fragile. Chen's presidential election was fortuitous on both occasions. His two opponents had split the traditional KMT vote in 2000, giving him a plurality of 38\% of the popular vote in that election. His margin of victory in 2004 was even smaller, a victory that was in part due to an election-eve assassination attempt on him. Chen's initiatives to promote Taiwan independence were more vulnerable to reversal due to narrow electoral mandate and lack of an institutional power base. Heterogeneous domestic interests made his initiatives possible in the first place but also caused the subsequent policy reversal. In the parlance of two-level games, the domestic and international coalition of forces were too fragile to sustain Chen's pro-independence drive. The DPP has tried to capitalize local political support and exploit the geographic cleavage that has divided Taiwan, with the northern part of the island dominated by the pan-Blue forces and the southern part dominated by the pan-Green forces. Yet, economic intercourse and the forces of globalization have strengthened the larger and more internationally-oriented companies that are overwhelmingly located in the north. By comparison, small and less competitive firms in the south have been hurt by international, including Chinese, competition. In other words, the globalization process and economic relations with the mainland China have had this additional effect in redistributing regional influence and sustaining the rapprochement across the Taiwan Strait. 


\section{Conclusions}

This article has analyzed the cyclical pattern of cross-Strait relations through three causal factors--the role of issue cycles, impulsive drivers for change, and the structural constraints that dampen change. It demonstrates that, given the current tacit agreement on the status quo, there are strong countervailing forces against major changes, especially those impulsive forces that try to play change into their advantages. The structural constraints are powerful and are becoming stronger as the underlying economic trends across the Strait, China-U.S. relations, and the "domestic headwind" in China and Taiwan make it more difficult for anyone who wants to "rock the boat."

A case can be made for cautious optimism about the future of cross-Taiwan Strait relations. The cross-Strait rapprochement since 2008 has brought peace and stability to the Taiwan Strait after years of tension and confrontation. Substantive dialogues were resumed in June 2008 and even institutionalized with direct participation by government officials in cross-Strait dialogues. The two sides have made progress in dialogues and expanding cross-Strait exchanges by focusing on an agenda of "economy first, politics second; easy issues first, difficult ones later". However, the current rapprochement based on the "constructive ambiguity" of the "1992 Consensus" may not an enduring one. Following an incremental approach and "shelving disputes and building mutual trust," the two sides of the Strait have harvested all low-hanging fruits and left the hardcore political impasse untouched. The political impasse in cross-Strait relations - the sovereignty issue concerning future cross-Strait political relations--remains a hindrance for future developments, and there seems no way to get around of it. Before it is too long, the current equilibrium may be punctuated by another impulsive change if rising nationalistic sentiment on the two sides leads to another confrontation over the "reunification or independence" issue. 